\title{
Relations between Levels of Government in Handling the Covid-19 pandemic in Indonesia: A Study on Relations between the Central Government and the Provincial Government of DKI Jakarta
}

\author{
Achmad Lutfi \\ Faculty of Administrative Science, Universitas Indonesia, Indonesia (email: achmad.lutfi@ui.ac.id) \\ Desy Hariyati \\ Faculty of Administrative Science, Universitas Indonesia, Indonesia (email: desy.hariyati@ui.ac.id)
}

\begin{abstract}
The Covid-19 pandemic has plagued various countries in this hemisphere. The spread of this pandemic has a significant impact on all aspects of life in various countries, including Indonesia. Various efforts have been made by both the central and regional governments in dealing with this problem, but in the process they are often faced with problems of differences in views and attitudes between levels of government, for example difference understanding that occurs between the Central Government and the Provincial Government of DKI Jakarta. This problem occurs because of weak inter-governmental coordination in making public policies. This ineffective inter-governmental relationship, of course, can cause public confusion in complying with all existing policies so that it will lead to not achieving the goal of handling cases. The purpose of this study is to analyze how inter-governmental relations in handling Covid-19 in Indonesia, especially between the Central Government and the Provincial Government of DKI Jakarta. The research method used in this research is literature study. While the data from the literature study is coded based on the indicators of the main theory. Result shows that there are a number of problems regarding the relation between central government and the government of DKI Jakarta Province in which most of the problems lie more on institutional and demographic factors rather than the other four factors.
\end{abstract}

\section{Keywords:}

covid-19; pandemic handling; intergovernmental relations; Indonesia; Jakarta

\section{Introduction}

On $2^{\text {nd }}$ March 2020 the Government of Indonesia announced that confirmed Covid-19 cases had been identified in Indonesia. This official statement was made by President Joko Widodo, accompanied by Health Minister Terawan Agus Putranto at the Merdeka Presidential Palace. The first two confirmed patients, a mother and a daughter, were 
suspected to have contracted the virus from a Japan national who had been confirmed positive and had visited Indonesia in February (Tempo, 2020).

Coronaviruses are a family of viruses that cause illness in humans and animals. In humans, these viruses can cause respiratory diseases including the flu and other more severe diseases including the Middle East Respiratory Syndrome (MERS) and Severe Acute Respiratory Syndrome (SARS) (WHOa, 2020). The current global pandemic is caused by a novel coronavirus, known as SARS-CoV-2. This virus and the disease it is caused were unknown before the first known outbreak in Wuhan, China in December 2019. To date the Covid-19 pandemic has hit countries across the globe.

The Covid-19 global pandemic poses a serious threat to the world population. Although this is not the first plague hitting many countries, all countries are currently fighting against this pandemic. Numerous mitigation measures have been taken, including travel bans, to suppress the spread of the virus and manage available resources to contain infection. Governments all over the world are deploying their economic resources in a scale like never before (Foreign Affairs, 2020).

The World Bank predicted that East Asia and the Pacific economy had been severely impacted by the Covid-19 pandemic (World Bank, 2020). Large-scale lockdowns have come at a high economic cost and led to a deep economic contraction. This, along with the sudden global monetary tightening, has led to a massive capital outflow at the regional level. Commodity exports have also suffered due to the sharp fall in the commodity prices. East Asia and the Pacific economy contracted by $1.2 \%$ in 2020 before it is predicted to climb to $5.4 \%$ in 2021. Among the largest economies in this region, Malaysia (-3.1\%), the Philippines (-1.9\%), and Thailand $(-5 \%)$ were predicted to undergo the largest contraction this year. This is potentially due to national lockdown, decline in tourism, disruption in trade and manufacturing, and impact of the financial market. Indonesian economic growth has been predicted to remain stagnant in 2020, whereas Vietnam's is expected to slow down to $2.8 \%$. Although contraction can be avoided, growth is estimated to be 5.1 percentage points and 3.7 percentage points lower than the estimates in January 2020.

Countries have taken different measures to respond to the Covid-19 global pandemic. Norway is thought to be one of the countries in Europe that has successfully handled the pandemic. Despite the lack of preparation in several aspects (Christensen \& Lægreid, 2020), 
the Norwegian government has been able to swiftly and effectively control the pandemic by adopting suppression strategy, followed by mitigation strategy according to collaborative and pragmatic decision-making, successful public communication, ample resources, and strong public trust in the government. Well implemented coordinated actions to block, trace, and isolate potential sources of infection, coupled with the high level of public compliance, have enabled Taiwan to control the Covid-19 pandemic (Huang, 2020). The handling of the Covid19 pandemic must be a priority to protect people, but this needs to be coupled with measures to mitigate the negative economic impact. Norway approach prioritizes health while at the same time also allocates adequate resources and stimulus package to assist those severely impacted and to stimulate the economy (Christensen \& Lægreid, 2020). To control the spread of the virus, the Australian government implemented a lockdown measure (Moloney \& Moloney, 2020). The Australian government's competent navigation through policy change amid the pandemic while considering Covid-19 clinical severity, national and subnational coordination and collaboration, and evidence-based science and medical analysis can be considered a model for other countries (Moloney \& Moloney, 2020). Those strategies are aimed at slowing the spread of the virus and at mitigating the negative impact brought about by the pandemic.

According to the Coronavirus Disease 2019 (Covid-19) Situation Report - 31 published by the WHO Country Office, on $28^{\text {th }}$ October the Government of Indonesia announced 400,483 confirmed Covid-19 cases (4,029 new cases), 13,612 deaths (100 new deaths), and 325,793 recovered cases from 502 districts in 34 provinces. On 30 $0^{\text {th }}$ October, 28,974 new Covid-19 cases and 406,945 cumulative confirmed cases reported nationally. The period between $21-27$ September 2020 recorded the highest number of weekly cases since the start of the pandemic with 30,537 new cases; average 4,362 new cases daily, a considerable increase compared to 3,756 new cases daily in the previous seven days. Per $30^{\text {th }}$ October 2020, 55.6\% confirmed cases were on Java; DKI Jakarta, East Java, Central Java, and West Java were the four provinces with the largest number of confirmed cases (WHO, 2020b). South Sulawesi in the $5^{\text {th }}$ rank was the only province outside Java with the highest number of confirmed cases. According to this data, Indonesia ranks 23th globally and $1^{\text {st }}$ in Southeast Asia as the country with the largest number of confirmed cases. 


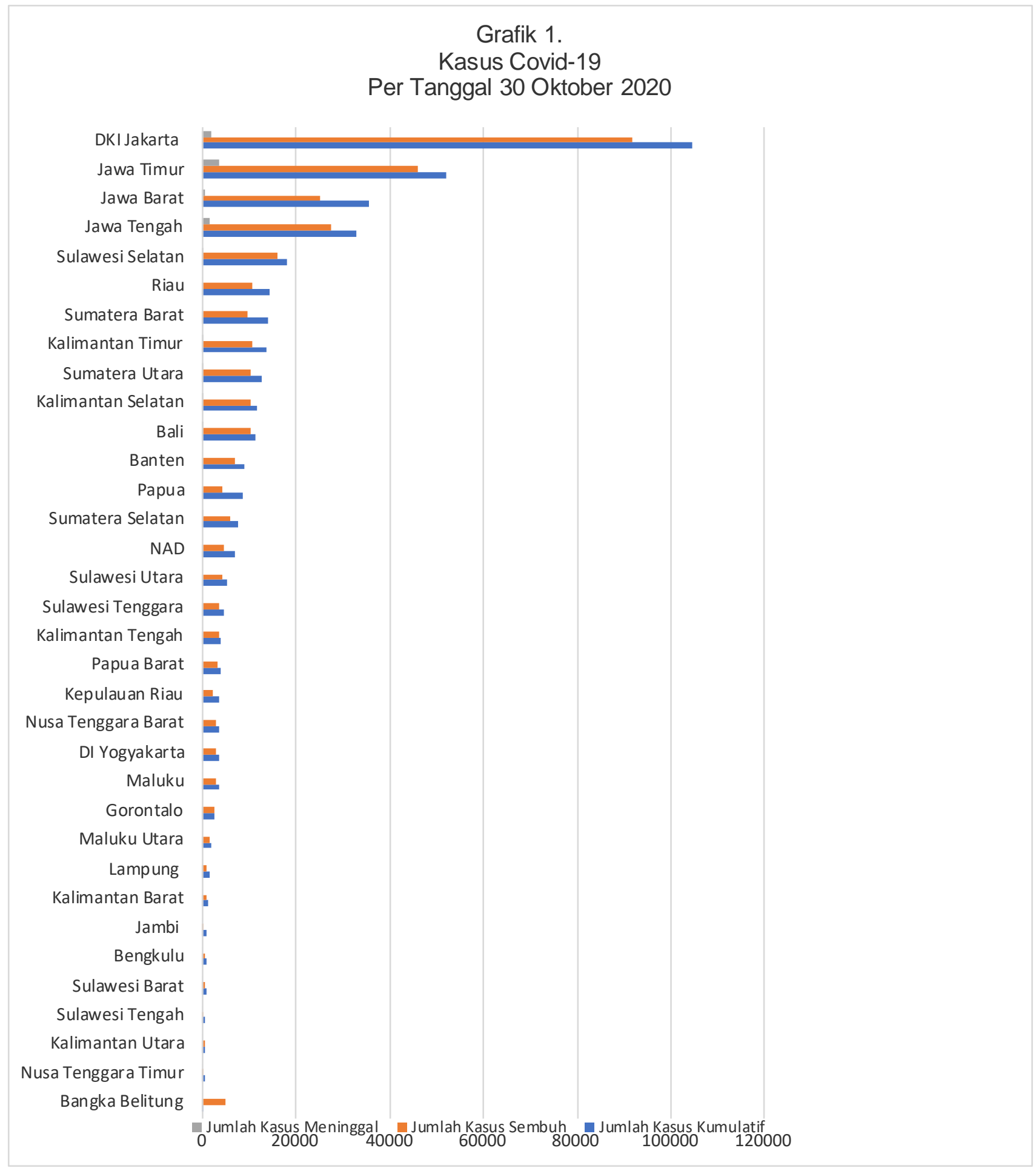

Source: $\quad$ https://covid19.kemkes.go.id/situasi-infeksi-emerging/info-corona-virus/situasi-terkiniperkembangan-coronavirus-disease-covid-19-31-oktober-2020/\#.X6aTd2gzbIU

It is worth noting that according to the Most Updated Development of Covid-19 released by the Indonesian Ministry of Health (per $30^{\text {th }}$ October 2020) $55.6 \%$ of the confirmed cases in Indonesia were in provinces on Java Island (Ministry of Health, 2020). The number of 
confirmed cases in DKI Jakarta accounted for $22.76 \%$ of the national count, followed by East Java $(12.83 \%)$, Central Java $(8.18 \%)$, and West Java $(8.82 \%)$. The report also mentions that during the same period the rate of recovered cases was at $82.14 \%$. East Java had the highest rate of recovered cases at $88.34 \%$, followed by DKI Jakarta (87.95\%), Central Java (83.52\%), and West Java (70.57\%). The high Covid-19 infection rates in the four provinces on Java Island are alarming, considering the fact that Java Island contributed more than $57 \%$ to Indonesian economy (Puspasari, 2020), so the unresponsive pandemic handling by the government potentially negatively impact the national economy.

Amid the alarmingly high number of confirmed cases in DKI Jakarta, intergovernmental relations have often become subject of debates. Such examples include the disagreements between the central government and a number of local governments on local lockdown (Indonews, 2020) and on the reopening of schools and other educational institutions (CNN Indonesia, 2020). More specifically, the central government and DKI Jakarta provincial government took different stands on several matters including the plan on massive testing, local lockdown measure, the operation of intercity and interprovince buses, and the exit dates of the large-scale social distancing measure, known as PSBB (Ridhoi, 2020).

The different stands described earlier are considered to result from the adversarial relationship between the central and local governments. This also suggests ineffective intergovernmental relations, resulting in disagreements potentially leading to confusion among the public. The Government of DKI Jakarta overseeing the country's capital has often been at odds with the central government on matters related to the handling of the Covid-19 pandemic. In light of this, this paper aims to analyze the relations between the central government and DKI Jakarta provincial government in the handling of Covid-19 pandemic.

All countries in the world have taken different measures to respond to the Covid-19 pandemic and made this their primary focus in their policies since the start of 2020. Policy measures have mainly been targeted to suppress rapid transmission of Covid-19 and to mitigate the impacts of the pandemic.

Health and economic recovery policies have been the main focus of the Government of Indonesia in response to the Covid-19 pandemic. According to the Constitution, the authority and responsibility related to health policy should be initiated by the Ministry of Health (Telaumbanua, 2020). However, the government's handling of the Covid-19 pandemic 
has shown that their health policy has proven ineffective at suppressing the spread of the virus as indicated by the increasing number of daily confirmed cases (Covid19.go.id, 2020). Regarding the economic recovery policy, the central government has also taken a series of measures to mitigate the negative effects of the pandemic. However, the central government policy has several times collided and overlapped with the measures taken by the local government.

The most important thing to understand the intergovernmental relations, between the central and local governments, is to understand the concept intergovernmental relations. Intergovernmental relations are defined as formal and informal mechanisms to ensure coordination and collaboration across different levels of government within the decentralized and federal political system (Grudel et al., 2017). This definition suggests that the sharing of power among the different levels and the different elites (from different backgrounds) is useful to ensure the relational functionality across governmental levels. Cross-level coordination is key because oftentimes overlapping competence and different policy require collaboration. Within intergovernmental relations there are several tendencies (1) intergovernmental relations as a collaborative process, (2) subnational government as an important policy actor and resource, (3) intergovernmental relations closely relating to collaborative governance, and (4) diversity in intergovernmental relations as a two-edged sword (Baracskay, 2013).

Weak collaboration between actors in the central and local governments and miscommunication between them potentially lead to failure in the policy implementation to tackle the Covid-19 pandemic (Tummers, 2014; Houngbo et al., 2017; Huang, 2020). Managing a pandemic, which is a moving target, requires agility from all levels of government as well as effective communication patterns and networks. Lack of agility and miscommunication can potentially result in failure to mitigate the impacts of the pandemic. The handling of the Covid-19 pandemic requires a strong intergovernmental cooperation and collaboration.

Collaborative governance is a common concept in the public administration literature, yet its definition remains ambiguous and its application inconsistent (Emerson et al., 2011). Collaborative governance can be broadly defined as decision-making and public policy management processes and structures involving people constructively across the boundaries 
of public bodies, levels of government, and/or public, private and civic domains, in order to achieve an otherwise unattainable public goal.

A focus on the relations between the central and local governments in the implementation of pandemic mitigation measures is expected to bring about positive impact towards more effective handling of the Covid-19 pandemic. Intergovernmental relations in the modern era not only focus on the relations between governments, but also consider the government responses to private and public sectors (Baracskay, 2013).

The pattern dynamics of intergovernmental relations illustrate policy implementation with regards to pandemic handling and the relational dynamics between the central and local governments. Both governments are expected to complement each other and implement mitigating measures in harmony because there has been a transfer of certain authority from the central government to the local government within the context of decentralization. However, the opposite often happens whereby the central government forces the local government to perform specific actions to implement a certain policy. In this context, the multilevel governance concept (Peter \& Pierre, 2001; Agranoff, 2004; Choi \& Wright, 2014) became relevant to analyze the intergovernmental relations between the central and local governments. Collaborative relations between the central and local governments can be seen from the non-coercive role of the central government towards the local government in policy making and implementation. Collaborative governance (LaFFiN, 2007; Agranoff, 2008; Emerson et al., 2012) between the central and local governments is an appropriate approach to scrutinize the model and phases of intergovernmental relations.

The multilevel governance approach can be understood as an intergovernmental relational patterns formed through the interactions among public authorities at different geographical jurisdictions, referring to hierarchical and vertical interactional dimension "from above to below" or vice versa (Hooghe \& Marks, 2003; Slaughter, 1997). This concept is often used by decision-making authorities to divert competence from the state in the face of an urgent policy challenge that is beyond the reach of the central government. Collaborative governance is often understood as collaborative inertia, so in order to solve a policy issue, an effective coordination cannot be done by the government unless they synergize and collaborate (Vangen \& Huxham 2010; McGuire 2006). 
Intergovernmental relations indicate structural, systemic, and institutional complexities within a country. Every country can take different measures to respond to various intergovernmental relations in order to create an effective pattern to solving public issues. There are six influential factors that form intergovernmental relations in each country, namely 1) historical factor, 2) demographic factor, 3) social and cultural factor, 4) constitutional and institutional factor, 5) political factor, and 6) circumstantial factor.

Processes and forms of intergovernmental relations within the conceptual frameworks of multilevel governance and collaborative governance have often been discussed separately in previous case studies. Those studies focused on the two concepts separately to analyze the forms of intergovernmental relations within a country. No prior studies have comprehensively applied the two concepts complementarily to study a policy in a country. This study fills this gap by applying the collaborative governance and multilevel governance concepts complementarily to analyze intergovernmental relations. More specifically this study analyzes policy related to Covid-19 global pandemic. There is also a gap in the literature of the intergovernmental relations that specifically examines this health policy.

\section{Methods}

To address the research question pertaining to effective intergovernmental relations in handling the Covid-19 pandemic, the researchers used a qualitative method by means of literature study within the framework of intergovernmental relations presented earlier. This literature study was conducted to examine media coverage of policy dynamics of the central government and DKI Jakarta provincial government in handling the Covid-19 pandemic. This study specifically focuses on one province, DKI Jakarta, for two reasons: DKI Jakarta as having the highest number of confirmed Covid-19 cases and DKI Jakarta as the capital of Indonesia, making coordination efforts between the central and provincial governments primarily crucial. Additionally, the handling of the pandemic in the capital can serve as a policy benchmark for other provinces.

The main data used in this study is media coverage of policy measures taken by both the central and DKI Jakarta provincial governments related to the handling of the pandemic. Literature coding was done in light of the theoretical framework. The coding results were then used to analyze the data to draw conclusions to address the research question. 


\section{Results and Discussion}

\section{Constitutional and institutional factor}

There has been lack of synergy in the policy measures taken by the central and DKI Jakarta provincial governments. When the provincial government attempted to enforce the large-scale social distancing measure, known as PSBB, the central government proposed to loosen the measure. These two were on different ends of the policy spectrum. The rationale for the provincial government's decision to enforce the social distancing measure was to save lives, which is the utmost priority. On the other hand, the rationale for the central government's proposal to loosen the measure was for economic recovery in order to prevent further economic impact as the pandemic continued (Rahmawati, 2020).

Prior to implementing the large-scale social distancing measure, DKI Jakarta provincial government had proposed a local lockdown measure. On one press briefing at the City Hall on 30 March 2020, DKI Jakarta Governor Anies Baswedan proposed to President Joko Widodo to put DKI Jakarta province into a lockdown. Under this proposed lockdown measure several key sectors would be allowed to remain in operation, including energy, food, health, communication and financial sectors. Other sectors would also likely to be allowed to remain open. On the following day, President Joko Widodo responded to the proposal by refusing to implement the lockdown measure. Through the presidential spokesperson, Presiden Joko Widodo rejected the proposal. This rejection was conveyed by the head of state during the closed meeting on 30 March 2020. "It was not accepted, automatically rejected," explained the spokesperson on 31 March 2020. Fadjroel, the spokesperson, further explained that the authority to implement a lockdown at provincial level is at the hand of the president. Provincial government can only implement small-scale lockdowns at the neighborhood and village levels in accordance with the policy of the head of local government (Supriatin, 2020).

On 31 March 2020, the central government issued three regulations, i.e. Government Regulation No.1 of 2020 on State Budget Policy on the Covid-19 Pandemic Handling, Presidential Decree No.11 of 2020 on Public Health Emergency, and Presidential Regulation No.21 of 2020 on Large-scale Social Distancing Measure (PSBB) in the Handling of the Covid19 Pandemic. According to the Government Regulation on Large-scale Social Distancing Measure (PSBB), Clause 6 states that the implementation of large-scale social distancing 
measure (PSBB) should be proposed by the head of local government to the Minister of Health. The same Regulation also stipulates the minimum measures including school and workplace closure, restrictions on religious activities, and restrictions on activities in public places, all of which had been implemented in DKI Jakarta and several other cities even before the Government Regulation was issued. This means that the central government only strengthened the measures already taken by provincial government (Ridhoi, 2020).

The disagreements over the enforcement versus loosening of the large-scale social distancing measure (PSBB) could be clearly seen from the statements made by the central and provincial government officials. One Coordinating Minister from the Indonesia Onward Cabinet proposed to loosen the large-scale social distancing measure (PSBB) by implementing Government Regulation No.21 Year 2020. This proposal was based on the evaluation conducted by the central government on the implementation of the social distancing measure already in place in several regions in Indonesia. Meanwhile DKI Jakarta provincial government took a different stand and proposed to continue the social distancing measure and even enforce it because the measure had not successfully brought the number of infections down in DKI Jakarta. The disagreements over the enforcement versus loosening of the largescale social distancing measure (PSBB) continued not only in the early days of the measure implementation but also as the provincial government extended and changed the status of the measure, for example from the large-scale social distancing measure (PSBB) to the large-scale social distancing measure transition (PSBB transisi) (Rahmawati, 2020).

In the early stage of the Covid-19 pandemic, DKI Jakarta provincial government's initiative to conduct tracing through massive testing was also not approved by the central government. This led to undetected Covid-19 cases in DKI Jakarta. It was suspected that the number of the then so-called Wuhan-pneumonia cases, before it was called Covid-19, in DKI Jakarta increased (Rahmawati, 2020).

DKI Jakarta Governor's policy measure regarding public transportation also received a negative response. The Governor placed a limit on the number of coaches in MRT and LRT in Jakarta in order to suppress the spread of the virus. The number of MRT coaches was reduced from the normal 16 to 4 coaches. MRT schedule was also made less frequent, from every 10 minutes to every 20 minutes. The same was for LRT schedule, from every 10 minutes to every 30 minutes. Public transport operating hours were also changed to only operating 
between 6 am and $6 \mathrm{pm}$. This measure was meant to minimize contact among passengers to reduce the spread of the virus. One day following the implementation of the measure by the Governor, President Joko Widodo made a statement. He instructed local governments to provide public transport services despite the increase of the Covid-19 cases. "Public transport services must be provided by the central and local governments," said the President at the Bogor Palace on Monday, $16^{\text {th }}$ March 2020. The President argued that this was important to reduce queues and crowding so that the public could maintain a safe distance from each other. "What's important is to reduce gatherings, queues, and crowding inside the public transport so that we can maintain a safe distance from each other," the President explained (Supriatin, 2020).

Besides putting a limit on the public transport managed by the provincial government through the provincial government owned enterprise, DKI Jakarta provincial government also attempted to control other public transport services. This measure was aimed at prohibiting the operations of inter-city inter-province buses, inter-province commuter buses, and tourist buses in Jakarta. This measure was not entirely the initiative of the provincial government; rather it was a decision made during a meeting with the related ministries, which are part of the central government. Head of DKI Jakarta Transport Agency, Syafrin Liputo stated the policy measure was decided during a coordination meeting with several representatives from the Ministry of Transport and others. The policy took effect starting Monday, 30 $0^{\text {th }}$ March 2020 at 6 pm. With the ban in effect, inter-city inter-province and interprovince commuter bus stations were planned to be temporarily closed, for example the one in Kalideres, West Jakarta. The closure of bus stations was hoped to suppress the spread of the virus in DKI Jakarta. On the very same day, the Ministry of Transport decided to postpone the policy implementation regarding the operation prohibition of inter-city inter-province buses, inter-province commuter buses, and tourist buses in Jakarta. The Ministry of Transport spokesperson, Adita Irawati, stated the postponement was based on the advice from the acting Minister of Transport (Luhut Pandjaitan). “On the advice of the acting Minister of Transport (Luhut Pandjaitan) the policy implementation is pending further policy study on the economic impact of the measure in line with the President's directions during the closed meeting," said Adita Irawati on Monday, 30th March 2020. This clearly shows the central government's inconsistence in the handling of the Covid-19 pandemic Supriatin. (2020). 
Another DKI Jakarta provincial government's proposal to mitigate the Covid-19 pandemic which was initially rejected by the central government and was then accepted is the repurposing of Kemayoran Athletes Village to become a Covid-19 Emergency Hospital. In one Covid-19 mitigation readiness meeting on 10 March 2020, DKI Jakarta Deputy Governor for Housing and Settlement, Suharti, proposed the repurposing of Kemayoran Athletes Village as a quarantine facility for Covid-19 suspects (ODP). At that time the central government already announced the $19^{\text {th }}$ confirmed case, and 15 of them were in DKI Jakarta. The repurposing proposal was responded by the central government eight days later. The Minister of Finance made a statement saying that Kemayoran Athletes Village as a state asset would be used as an isolation facility for Covid-19 patients. She added that the repurposing of this facility was already discussed with the National Agency for Disaster Management (BNPB). One reason for this repurposing was because Kemayoran Athletes Village had not been optimally utilized meanwhile there was a dire need for health facilities to quarantine Covid-19 patients. Also considering the readiness of Kemayoran Athletes Village, it was then officially repurposed to be the Covid-19 Emergency Hospital on 26 March 2020 (tirto.id, 2020).

Intergovernmental relations in the handling the Covid-19 pandemic, between the central and DKI Jakarta provincial governments, were highly dynamic. This shows that responses from each governmental level in response to a developing phenomenon have to be managed through policy measures.

\section{Historical factor}

Since the independence, intergovernmental relations in Indonesia between the central and local governments have been particularly dynamic. This is akin to a motion in a pendulum whereby the pendulum bobs swing back and forth. Demand for more space in exercising local autonomy has often been expressed by local governments when the central government is increasingly more centralistic in managing their relations with local governments. In the beginning of the Covid-19 pandemic, the central and local governments were in good terms. However, as the pandemic developed, the relations evolved and became less harmonious due to the public dissatisfaction with the central government's handling of the Covid-19 pandemic. 


\section{Demographic factor}

In terms of demography, DKI Jakarta province has a special status as the capital of the country while its autonomy remains at the provincial level. DKI Jakarta province has a land area of $662.33 \mathrm{~km}^{2}$ and a sea area of $6,977.5 \mathrm{~km}^{2}$ and 110 islands in the Thousand Islands area. In terms of administrative governance, DKI Jakarta province comprises five administrative cities and one administrative district. DKI Jakarta population was 10,557,810 with an annual birthrate of 1.19 according to the 2010 census data, and a population density of 15,900 per 1 $\mathrm{km}^{2}$ in 2019. With this demography, it is certainly a massive challenge for DKI Jakarta provincial government to mitigate and navigate the course of the Covid-19 pandemic to prevent more serious impact in terms of public health and ultimately public safety (Jakarta in Figure, 2020).

The residents of DKI Jakarta come from different regions in Indonesia and some are even from outside Indonesia. People of different ethnicities and religions can be found in Jakarta. This diversity also brought with it diversity in customs, cultures, and beliefs to Jakarta, so Jakarta can be considered a mini Indonesia. All the socio-cultural factors in Jakarta also contribute to the massive challenge the provincial government has to face in the handling of the Covid-19 pandemic.

According to the Law of the Republic of Indonesia No.29 of 2007, DKI Jakarta Province holds a status as the capital of the Republic of Indonesia. This status has often caused interventions from the central government to the provincial government autonomy. The status of DKI Jakarta provincial government is the same as other provincial governments. Government agencies under DKI Jakarta provincial government also have the same responsibilities and authorities as other similar agencies in other provinces. DKI Jakarta as the capital of Indonesia, which is often viewed as the representation of Indonesia, is what makes it different from other provinces. Furthermore, the fact that the central government is located in DKI Jakarta often leads to extra intervention to the authority of the provincial government, which certainly is not an issue in other provinces. This is one of the reasons why policy measures taken by DKI Jakarta provincial government are often seen as contradictory to those by the central government although quite often some of the policy measures taken by the provincial government are also adopted by the central government. 


\section{Political Factor}

One cannot ignore the fact that the executive head of the provincial government and the executive head of the central government are affiliated to different political parties. Different political affiliations of political leaders can contribute to the divergent leadership styles. A government leader should be the leader of all the societies regardless of the political leanings. Contradictory policy making will potentially lead not only to the abandonment of the public interest but also to confusion among the public resulting from the different policy measures taken by the leaders.

The handling of the Covid-19 pandemic is certainly a massive challenge, both at the global and national levels, and it requires coordinated and comprehensive measures. Collaborative actions between the central and local governments are imperative. Public policy resulting from coordinated collaborative measures by governments at different levels can potentially suppress the spread of the virus and gradually overcome the negative impact brought about by the pandemic.

\section{Conclusion}

From findings and discussion presented above, two conclusions can be drawn regarding the intergovernmental relations in the handling of the Covid-19 pandemic between the central and DKI Jakarta provincial governments. First, a number of policy measures initiated or taken by DKI Jakarta provincial government were often viewed as inappropriate by the central government although those policy measures were still implemented. Second, viewed from various factors, particularly those outlined by Cameron (2002), several factors could be seen as the driving force for the rather adversarial intergovernmental relations between the central government and DKI Jakarta provincial government. The relations appeared to be rather adversarial and potentially causing confusion among the public.

Considering the importance and urgency of the handling of the Covid-19 pandemic, a set of measures need to be taken. First, partial interests should be put aside in order to formulate comprehensive policy measures. Second, intergovernmental collaboration should be fostered to produce comprehensive policy measures in the handling of the pandemic. Third, synchronization and harmonization in policy implementation should be foregrounded to ensure optimum policy output and outcome. 


\section{Acknowledgment}

The study reported in this paper is part of a larger PDUPT study entitled “Intergovernmanetal Relation in Handling the Covid-19 Pandemic" conducted by Democracy and Local Governance Research Cluster, Faculty of Administrative Science, Universitas Indonesia, led by Prof. Dr. Irfan Ridwan Maksum, M. Si. The PDUPT study on which this paper is based was still continuing when this paper was written. Part of the data and theoretical frameworks used in this paper is the collaborative work of a team of researchers, in which the authors are responsible for the DKI Jakarta Province case study.

\section{Reference}

Adilah, R. Y. (2020, July 16). Tembus 81.668 Orang, Kasus Covid-19 di Indonesia Tertinggi di Asia Tenggara. Retrieved from https://www.merdeka.com/tembus-81668-orangkasus-covid-19-di-indonesia-tertinggi-di-asia-tenggara.html

Agranoff, R. (2004). Autonomy, devolution and intergovernmental relations. Regional \& Federal Studies, 14(1), 26-65.

Agranoff, R. (2008). Intergovernmental and network administration, accountability, and performance: Symposium introduction. Public Performance \& Management Review, 31(3), 315-319.

Baracskay, D. (2013). Future directions in intergovernmental relations. Journal of Health and Human Services Administration, 252-269.

Bryson, J. M., Crosby, B. C., \& Stone, M. M. (2006). The design and implementation of CrossSector collaborations: Propositions from the literature. Public administration review, 66, 44-55.

Cameron, D. (2001). The structures of intergovernmental relations. International Social Science Journal, 53(167), 121-127.

Choi, Y. S., \& Wright, D. S. (2014). Intergovernmental relation (IGR) in Korea and Japan: Phases, patterns, and progress toward decentralization (local autonomy) in a transpacific context. International Review of Public Administration, 9(1), 1-22. 
Christensen, Tom and Per Lægreid. (2020). Balancing Governance Capacity and Legitimacy: How the Norwegian Government Handled the COVID-19 Crisis as a High Performer. Public Administration Review 80 (5): 774-779.

CNN. COM. (2000). https://www.cnnindonesia.com/nasional/20200817135742-20536532/ramai-ramai-tolak-keputusan-nadiem-buka-sekolah-saat-pandemi diakses 07-10-2020.

Covid-19, G. T. (2020, July 16). Retrieved from Gugus Tugas Percepatan Penanganan Covid19: https://covid19.go.id/

Covid19.go.id. 2020. Peta Pesebaran. Diunggah pada 17 Juli 2019. https://covid19.go.id/petasebaran

Emerson, K., Nabatchi, T., \& Balogh, S. (2012). An integrative framework for collaborative governance. Journal of public administration research and theory, 22(1), 1-29.

Foreign Affairs. (2020). https://www.foreignaffairs.com/articles/united-states/2020-0806/coronavirus-depression-global-economy

Gopinath, G. (2020, May 19). World Economic Forum. Retrieved from https://www.weforum.org/

Health, E. i. (2020, June 30). Emerging COVID-19 Success Story: Vietnam's Commitment to Containment. Our World in Data.

Hooghe, L., \& Marks, G. (2009). A postfunctionalist theory of European integration: From permissive consensus to constraining. British journal of political science, 1-23.

Houngbo, P. T., Buning, T. D. C., Bunders, J., Coleman, H. L., Medenou, D., Dakpanon, L., \& Zweekhorst, M. (2017). Ineffective healthcare technology management in Benin's public health sector: the perceptions of key actors and their ability to address the main problems. International Journal of Health Policy and Management, 6(10), 587.

Huang, Irving Yi-Feng. (2020). Fighting COVID-19 through Government Initiatives and Collaborative Governance: The Taiwan Experience. Public Administration Review 80 (4): 665-670.

Indonews.id. (2020). https://indonews.id/artikel/28667/Polemik-Daerah-dan-Pusat-soalCovid-19-Pengamat-Pemerintah-Pusat-tanpa-Parameter-Kebijakan/ diakses 07-102020, 0934 
Kemenkes RI (2020a). Situasi Terkini Perkembangan Corona Virus Disease Covid-19, 31 Oktober 2020. https://covid19.kemkes.go.id/situasi-infeksi-emerging/info-coronavirus/situasi-terkini-perkembangan-coronavirus-disease-covid-19-31-oktober2020/\#.X6aTd2gzbIU

Kössler, K., Woelk, J., Heinemann-Grüder, A., \& Keil, S. (2017). Intergovernmental Relations: Meaning and Relevance for Conflict Management.

Krane, D., \& Leach, R. H. (2007). 12 Federalism and Intergovernmental Relations: Theories, Ideas, and Concepts.

Labs, A. (2020, June 30). Emerging COVID-19 Success Story: South Korea Learned the Lessons of MERS. Our World In Data.

LaFFiN, M. (2007). Comparative british central-local relations: Regional centralism, governance and intergovernmental relations. Public Policy and Administration, 22(1), 74-91.

Moloney, Kim and Susan Moloney. (2020). Australian Quarantine Policy: From Centralization to Coordination with Mid-Pandemic COVID-19 Shifts. Public Administration Review 80 (4): 671-682.

Peters, B. G., \& Pierre, J. (2001). Developments in intergovernmental relations: towards multilevel governance. Policy and Politics, 29(2), 131.

Pusparisa, Y. (2020, July 16). Dunia di Ambang Krisis Ekonomi Terburuk. Retrieved from https://katadata.co.id

Puspasari, R. (2020, July 10). Kinerja APBN Semester-I untuk Respon Pandemi Covid-19. Retrieved from Kemenkeu: https://www.kemenkeu.go.id/

Rahmawati, Fitria, (2020). Beda Pendapat Mahfud MD dan Anies Soal PSBB. https://www. ayojakarta.com/read/2020/05/03/16843/beda-pendapat-mahfud-md-dan-anies-soalpsbb.

Reuters. (2020, July 16). Retrieved from Reuters: https://www.reuters.com/

Ridhoi, M. A. (2020, May 12). Anies dan Pemerintah Pusat Selisih Tangani Corona, Dampaknya ke Publik. Retrieved from Katadata: https://katadata.co.id/berita/2020/05/12/anies-dan-pemerintah-pusat-selisihtangani-corona-dampaknya-ke-publik

Slaughter, A. M. (1997). The real new world order. Foreign affairs, 183-197. 
Supriatin. (2020). Kebijakan Anies Terkait Corona Covid-19 yang Ditangguhkan Jokowi. https://www.liputan6.com/news/read/4216916/3-kebijakan-anies-terkait-coronacovid-19-yang-ditangguhkan-jokowi

Syambudi, I. (2020, June 9). Perseteruan Risma dan Khofifah di Zona Merah Corona. Retrieved from Tirto: https://tirto.id/perseteruan-risma-dan-khofifah-di-zona-merah-coronafF6Z

Telaumbanua, D. (2020). Urgensi Pembentukan Aturan Terkait Pencegahan Covid-19 Di Indonesia. QALAMUNA: Jurnal Pendidikan, Sosial, dan Agama, 12(1), 59-70.

Tirto.di. (2020). https://tirto.id/ramai-ramai-istana-jegal-kebijakan-anies-hadapi-covid-19$\mathrm{eJZB}$

Tummers, L., \& Bekkers, V. (2014). Policy implementation, street-level bureaucracy, and the importance of discretion. Public Management Review, 16(4), 527-547.

Vangen, S., \& Huxham, C. (2003). Enacting leadership for collaborative advantage: Dilemmas of ideology and pragmatism in the activities of partnership managers. British Journal of Management, 14, S61-S76.

WHO. (2020a). https://www.who.int/emergencies/diseases/novel-coronavirus-2019/questionand-answers-hub/q-a-detail/q-a-coronaviruses.(03102020-0947)

WHO. (2020b). Indonesia Situation Report - 27, http://www.who.int/Indonesia.

Wieler, L., Rexroth, U., \& Gottschalk, R. (2020, June 30). Emerging COVID-19 Success Story: Germany's Strong Enabling Environment. Our World In Data.

World Bank. (2020). Global Economic Prospect June 2020. 